\title{
Monitoring and modeling the dispersion of produced water on the Scotian Shelf
}

\author{
Haibo Niu', Kenneth Lee², Brian Robinson ${ }^{3}$, Susan Cobanli ${ }^{3}$ and $\mathrm{Pu} \mathrm{Li}^{{ }^{*}}$
}

\begin{abstract}
Background: Produced water from offshore oil and gas platforms is often disposed of directly into the sea, and there has been concern that this discharge might have deleterious effects on the marine environment. To help understand the patterns of dispersion and dilution of produced water discharges, and their potential effects, a combined modeling and monitoring study was conducted.

Results: Chemical analysis of representative produced water samples recovered from the Sable Offshore Energy Project (SOEP) Venture platform showed elevated concentrations of several organic and inorganic compounds of environmental concern; however, of the 25 stations sampled within $500 \mathrm{~m}$ of the platform, only one station, NE50, located $50 \mathrm{~m}$ to the northeast, showed chemicals associated with produced water at levels significantly above background values. The Dose-related Risk and Effect Assessment Model (DREAM) was used to evaluate the fate and transport processes of produced water after discharge. The results revealed that the near background level concentrations detected at the 26 stations were due to sampling outside the narrow plume boundary. This indicated that there was no accumulation of pollutants near the platform except inside the narrow plume.

Conclusion: The comparison of modeled and empirical data showed that the DREAM model can effectively predict plume behaviour. The results agreed well with the monitoring data and simulated the location of the plume as it changed continuously with the tidal currents. The model illustrated that elevated concentrations within the produced water plume occur only near the vicinity of the discharge.
\end{abstract}

Keywords: Produced water, Monitoring, Modeling, Dispersion, Scotian Shelf, Sable offshore energy, Venture platform, Simulation, Oil and gas, Discharge, Marine environment

\section{Background}

The exploration and extraction of offshore oil and gas requires the disposal of produced water in the marine environment. Produced water is the aqueous fraction extracted along with the hydrocarbons from geological formations, and consists of formation water (water naturally present in the reservoir), flood water (seawater previously injected into the formation to maintain reservoir pressure), and condensed water (in the case of gas production). Produced water is the largest waste stream associated with production and it contains various naturally occurring and production chemicals, some

\footnotetext{
*Correspondence: Pu.Li@dal.ca

1 Department of Engineering, Dalhousie University (Truro Campus), Truro, NS B2N 5E3, Canada

Full list of author information is available at the end of the article
}

of which may pose a threat to water column organisms, while others, such as metals and high molecular weight aromatic and saturated hydrocarbons, may accumulate in sediments (Somerville et al. 1987; Neff 2002; Durell et al. 2004; Lee et al. 2004; Bakke et al. 2013). A number of field monitoring and modeling studies have been conducted to study the effects of produced water discharges in the North Sea (Johnsen et al. 1998; Durell et al. 2004, 2006; Neff et al. 2006; Hylland et al. 2008), but only a limited number of studies have been performed off the east coast of Canada (DeBlois et al. 2004; AMEC and ConestogaRovers and Associates 2008).

Oil and gas activities off eastern Canada have increased significantly over the past few years and there are several producing fields on the Grand Banks and Scotian Shelf. Since December 1999, the Sable Offshore Energy Project 
(SOEP) operated by ExxonMobil and partners has been producing natural gas and discharging produced water from five offshore facilities near Sable Island, which is located approximately $225 \mathrm{~km}$ off the coast of Nova Scotia, on the Scotian Shelf (Fig. 1). The maximum discharge $\left(523 \mathrm{~m}^{3} /\right.$ day) from SOEP facilities are only about $5 \%$ of the discharge from other fields like Hibernia $\left(14,300 \mathrm{~m}^{3} /\right.$ day) on the Grand Banks (Fraser et al. 2006; CNSOPB 2010), yet the concentrations of some of the constituent chemicals in the SOEP produced water, for example, phenols, iron and ammonia, are much higher. For example, iron levels in Venture's produced water are about 58 times that of Hibernia's. As the SOEP facilities are close (about $45 \mathrm{~km}$ ) to the Gully Marine Protected Area (DFO 2014), it was considered important to study the transport of their produced water through the marine environment.

Although an environmental effects monitoring program has been annually conducted around the SOEP platforms, it mainly focused on the produced water chemistry and toxicity to mussels. The program did not study the transport and dispersion of the produced water (AMEC and Conestoga-Rovers and Associates 2008;
DFO 2009). To address this issue, the Centre for Offshore Oil, Gas and Energy Research (COOGER) in the Department of Fisheries and Oceans (DFO), in partnership with AMEC Earth and Environmental, conducted a research program in July 2009 on produced water from the Venture offshore production facility on the Scotian Shelf (Fig. 1). This platform was chosen because it has the greatest discharge volume among the five SOEP facilities, and is closest to the Gully marine protected area.

The main purpose of the research was to develop an insight into the character and composition of the produced water, and to monitor the environmental concentrations of associated chemicals. The empirical data to be used in a fate and transport model would allow industry operators, scientists and regulators to predict the movement, concentration and environmental risk posed by produced water at sea.

\section{Methods}

This study includes three major components: (1) field work onboard a ship to collect raw produced water from the facility and to conduct water column sampling at a number of pre-determined stations around the platform,

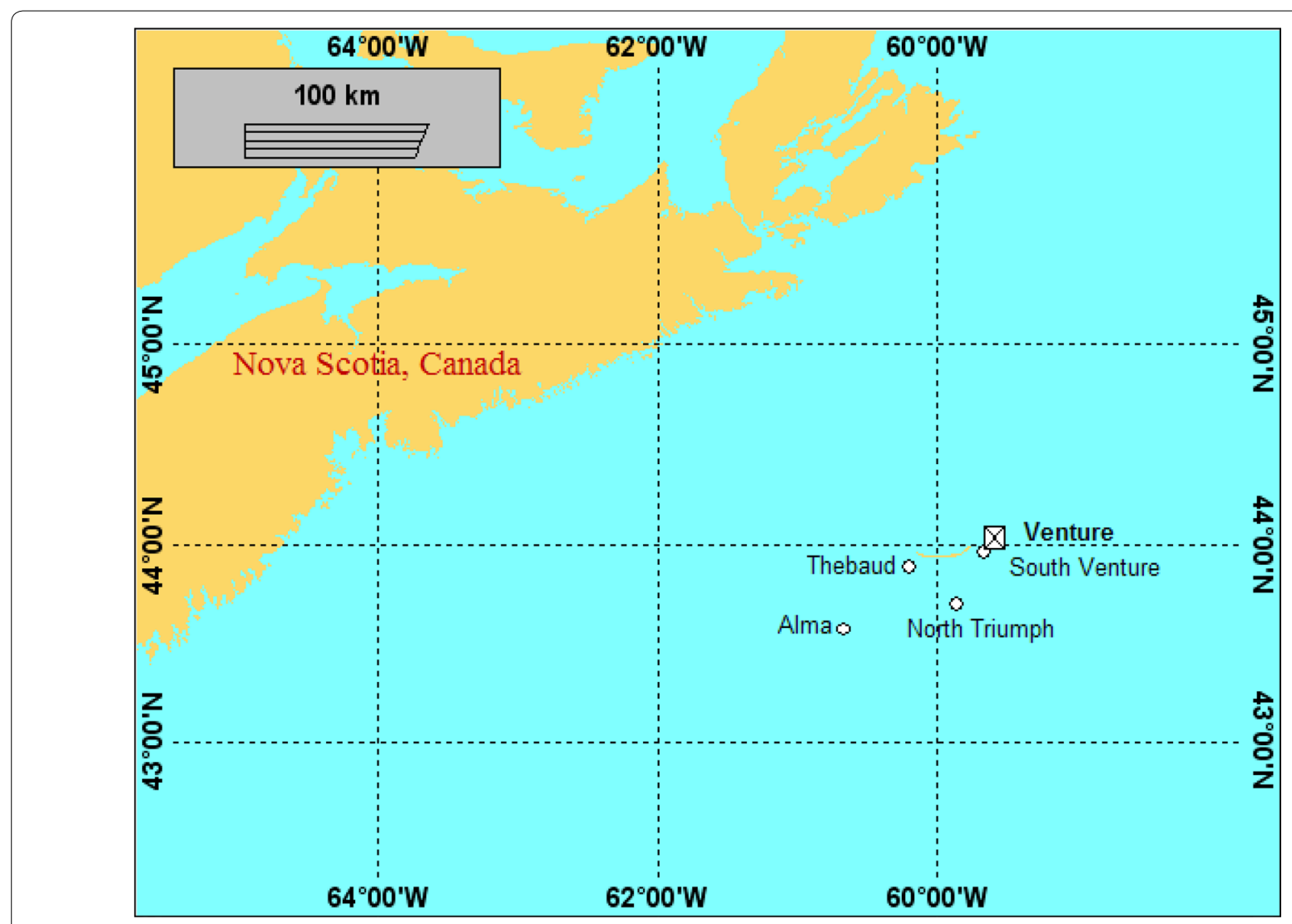

Fig. 1 Location of SOEP production facilities 
(2) laboratory chemical analyses of the water samples, and (3) simulation of the produced water trajectory and behaviour with comparisons to the field measurements.

\section{Field work}

Field work was conducted compliments of the supply vessel, MV Ocean Tern. Samples of raw Venture produced water were drawn by platform operators from a point in the process stream following treatment for regulatory compliance before discharge. Samples were transported in acid-rinsed $10 \mathrm{~L}$ Nalgene ${ }^{\circledR}$ HDPE jerricans to the Bedford Institute of Oceanography for analysis.

To design the sampling program for Venture, it was necessary to know the ocean current behaviour at the site. Since there was no current meter mooring, currents determined with an ocean circulation model were used (Brickman and Drozdowski 2012). The weekly averaged current data from April 2005 to December 2008 were analyzed. It was found that the mean weekly direction of flow was primarily southeast. Consequently, sampling locations covered all directions, but the focus was southeasterly. Since the zone of spreading was not expected to extend far due to the low volume of discharge
(94-133 $\mathrm{m}^{3} /$ day) for the study period, the majority of sampling took place in the near-field zone around the platform $(0-500 \mathrm{~m})$. A total of 25 stations within $500 \mathrm{~m}$ were sampled (Fig. 2). Two additional locations at 1 and $5 \mathrm{~km}$ southeast of the platform were sampled to ensure the capture of any detectable plume. A station at $18 \mathrm{~km}$ from the platform (SE1000) was chosen as a 'clean' reference. Each station was given an alpha-numeric designation to indicate the relative direction (e.g. SE $=$ southeast, $\mathrm{NW}=$ northwest, etc.) and approximate distance from the platform (e.g. $350=350 \mathrm{~m}, 5000=5000 \mathrm{~m}$ ). There was a discrepancy margin of about 3-26 m between the labelled distance and the actually distance due to the difficulty in positioning the ship in the open ocean.

At each of the 28 stations, conductivity, temperature and depth (CTD) profiles were obtained with a SeaBird SBE25 (Sea-Bird Electronic Inc. 2009). Water samples were collected over the side of the ship with a portable winch and davit system. This system was used to raise and lower various pieces of sampling equipment, including $5 \mathrm{~L}$ Niskin bottles and the Seabird CTD (Figs. 3, 4). Samples were collected at 2 and $10 \mathrm{~m}$ below the surface, and $2 \mathrm{~m}$ off the bottom using external spring

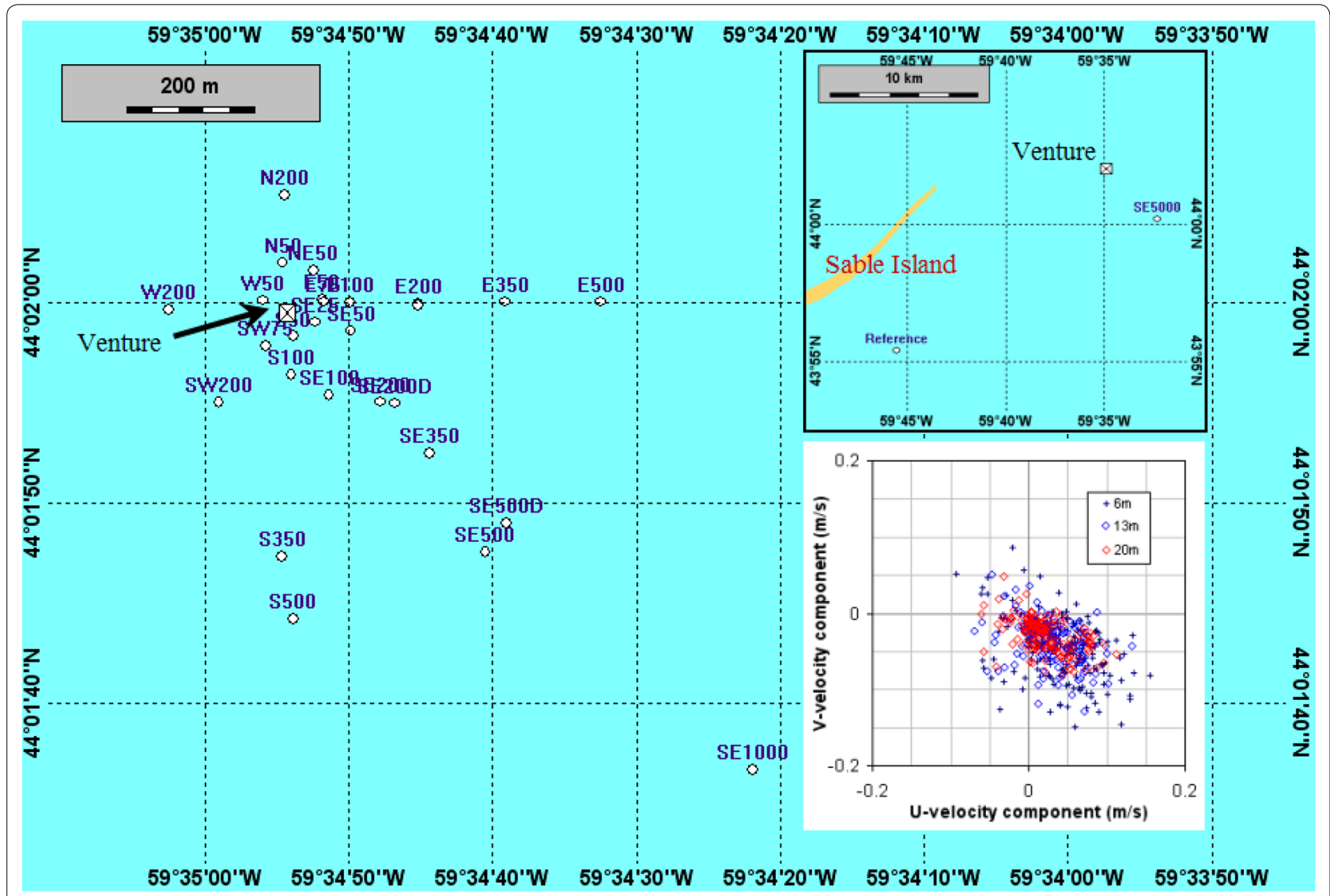

Fig. 2 Sampling stations and the current velocity component in the vicinity of the Venture production platform 


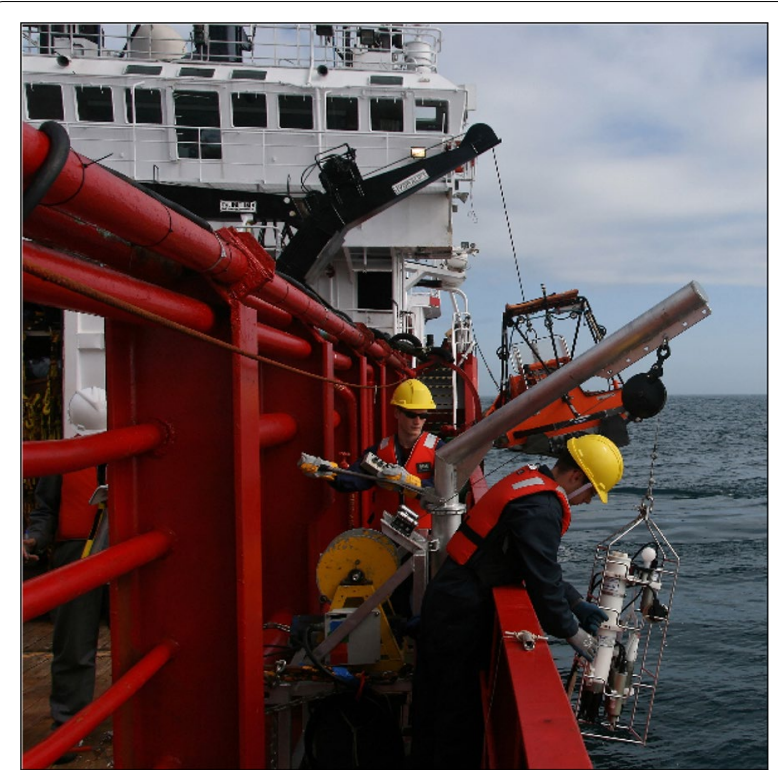

Fig. 3 Field deployment of the CTD sampler

Niskins for inorganics, and internal spring Niskins for all other parameters. To obtain a water sample, an open Niskin was attached to the winch cable, lowered into the water, and fired with the messenger. Once the Niskin was brought back onboard, the water was sub-sampled into various containers for analysis of nutrients, salinity, alkylated and nonyl phenols, polycyclic aromatic hydrocarbons (PAHs), aliphatic hydrocarbons, inorganic metals, and benzene, toluene, ethylbenzene and xylene (collectively known as BTEX).

\section{Chemical analyses}

PAHs and aliphatic hydrocarbons were analyzed based on a modified version of EPA Method 8270 (US EPA 2007a). Alkylated and nonyl phenols were processed according to a modified version of EPA Method 8041 (US EPA 2007b). For the analysis of BTEX, a modified version of EPA Method 8240 (purge and trap) was used (US EPA 1994).

Polycyclic aromatic hydrocarbons (PAH) and aliphatic hydrocarbons were analyzed based on a modified version of EPA Method 8270. The $1 \mathrm{~L}$ produced water sample is spiked with a surrogate standard containing a series of deuterated aliphatic and aromatic hydrocarbons, and extracted with dichloromethane in a separatory funnel. The solvent is concentrated on a TurboVap and the extract is purified on a silica gel column. The purified extract is exchanged into isooctane and spiked with internal standards. Samples are analyzed using an Agilent 6890 Gas Chromatograph (GC) coupled to a 5975 Mass Spectrometer (MS). The column is a Supelco MDN-5s

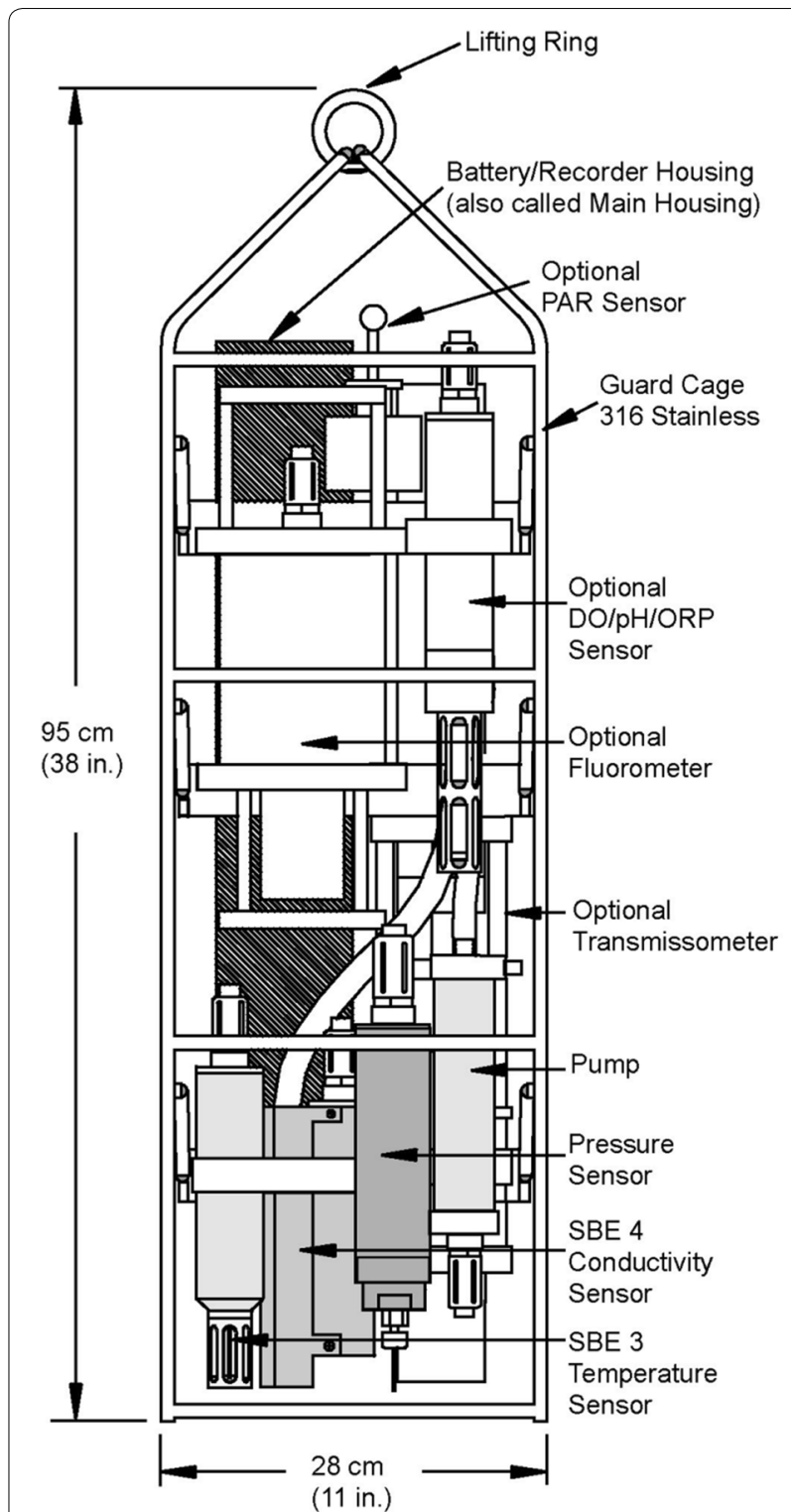

Fig. 4 Details of the design for the Seabird SBE25 CTD sampler (SeaBird Electronic Inc. 2009)

$30 \mathrm{~m} \times 250 \mu \mathrm{m} \times 0.25 \mu \mathrm{m}$ (length $\times$ i.d. $\times$ film thickness) with a $1 \mathrm{~m}$ retention gap of deactivated fused silica. The sample is injected using the oven track mode with a sample injection volume of $1 \mu \mathrm{L}$. Helium is used as a carrier gas with a flow rate of $1.0 \mathrm{~mL} / \mathrm{min}$. The oven temperature program is set to hold $85^{\circ} \mathrm{C}$ for $2 \mathrm{~min}$, followed by a ramp to $280^{\circ} \mathrm{C}$ at $4{ }^{\circ} \mathrm{C} / \mathrm{min}$ which is held for $20 \mathrm{~min}$ for a total run time of $70.75 \mathrm{~min}$. The mass spectrometer is operated in the selected ion monitoring (SIM) mode with specific ions and retention windows applied for each compound. Samples are calibrated against a sevenpoint calibration curve containing a mixture of aliphatic 
hydrocarbons as well as parent and alkyl PAH. For some of the alkyl PAH where standards were not available, the response of the parent PAH is used for quantification.

\section{Phenols}

Alkylated and nonyl phenols were processed according to a modified version of EPA Method 8041. Briefly, the $1 \mathrm{~L}$ produced water sample is acidified with $6 \mathrm{~N} \mathrm{HCl}$ to a $\mathrm{pH}<2$ and extracted in a separatory funnel with dichloromethane. The same GC-MS for PAH analysis was used for phenol analysis but the sample for phenol analysis was injected using the cool-on-column mode with a sample injection volume of $1 \mu \mathrm{L}$. The oven temperature program is set to hold $55^{\circ} \mathrm{C}$ for $2 \mathrm{~min}$, followed by a ramp to $100^{\circ} \mathrm{C}$ at $10^{\circ} \mathrm{C} / \mathrm{min}$ which is held for $2 \mathrm{~min}$, a ramp to $115^{\circ} \mathrm{C}$ at $1{ }^{\circ} \mathrm{C} / \mathrm{min}$ which is held for $2 \mathrm{~min}$, and a ramp to $220^{\circ} \mathrm{C}$ at $20^{\circ} \mathrm{C} / \mathrm{min}$ which is held for $4 \mathrm{~min}$ for a total run time of $34.75 \mathrm{~min}$. Samples are calibrated against a tenpoint calibration curve.

\section{BTEX}

For the analysis of BTEX, a modified version of EPA Method 8240 (purge and trap) is used. The instrument consists of a Teledyne Tekmar Purge and Trap system coupled to the GC-MS. Samples are collected in $40 \mathrm{~mL}$ purge and trap vials, and an autosampler is used to dispense $5 \mathrm{~mL}$ into the purge chamber. The sample is purged with helium for $11 \mathrm{~min}$, followed by a desorption time of $2 \mathrm{~min}$. The GC is run in split/splitless mode with a ratio of 50:1 with the oven temperature program set to hold $50{ }^{\circ} \mathrm{C}$ for $8 \mathrm{~min}$, followed by a ramp to $60{ }^{\circ} \mathrm{C}$ at $4{ }^{\circ} \mathrm{C} / \mathrm{min}$ and then a ramp to $280{ }^{\circ} \mathrm{C}$ at $40{ }^{\circ} \mathrm{C} / \mathrm{min}$ for a total run time of $18 \mathrm{~min}$.

\section{Metals}

Raw produced water was sub sampled into $250 \mathrm{~mL}$ plastic bottle and acidified with $1 \mathrm{~mL} / \mathrm{L}$ high pure nitric acid. The raw produced water was then diluted with Milli$\mathrm{Q}$ water to desired salinity and analysed by inductively coupled plasma mass spectrometry (ICP-MS) instrumentation for the full spectrum of metals. For seawater samples, the metal analysis was focused on Fe as its concentration is about $7 \times 10^{4}$ times higher than the reference value which makes it suitable as tracer to study the dispersion behaviours of produced water. The determination of Fe for seawater samples was done by adapting the in line ICP-MS method used by NRC in Ottawa to extract metals from seawater. Seawater was buffered to pH 5.2 before passed through a column of Toyopearl AFChelate-650M resin. The metals were then eluded with $1 \mathrm{M} \mathrm{HNO}_{3}$ and analysed by Zeeman AA spectroscopy (Willie et al. 1998). $\mathrm{Cu}$ and $\mathrm{Ni}$ was also analyzed using same method.

\section{Nutrients}

Ammonia was analyzed using fluorometric method, which is based on the reaction of ammonia with orthophtaldialdehyde (OPA) and sulfite (Kérouel and Aminot 1997). Industrial Method 155-71W (Technicon Industrial Systems 1973) adapted from Murphy and Riley (1962) was used to determine the phosphate. It is based on the formation of a phosphomolybdenum blue complex, read colorimetrically at $880 \mathrm{~nm}$, produced by the reaction of phosphate with an acidic ammonium molybdate solution containing a small amount of antimony and ascorbic acid. The method for Nitrate/Nitrite analysis was the Industrial Method 158-71W (Technicon Industrial Systems 1979) adapted from Armstrong et al. (1967). This is based on reducing nitrate to nitrite by a copper-cadmium reductor column. The nitrite ion reacts with sulphanilamide under acidic conditions to form a diazo compound. This compound couples with $\mathrm{N}$-1-naphthylethylenediamine dihydrochloride to form a reddish-purple azo dye, which is read colorimetrically at $550 \mathrm{~nm}$. Nitrite is determined with identical chemistry but omitting the coppercadmium column from the sample stream. Silicates were analyzed using the Industrial Method 186-72W (Technicon Industrial Systems 1977) adapted from Strickland and Parsons (1972). The determination of soluble silicates in seawater is based on the reduction of a silicomolybdate in acidic acid solution to 'molybdenum blue' by ascorbic acid which is read colorimetrically at $660 \mathrm{~nm}$.

\section{Modeling the fate and transport process}

The three-dimensional, multiple component pollutant fate and transport DREAM (Dose-related Risk and Effects Assessment Model) was used in this study (Reed and Hetland 2002; Neff et al. 2006; Reed and Rye 2011). The present version includes exposure, uptake, depuration, and effect calculations for fish and zooplankton exposed to complex mixtures of chemicals. Governing physical-chemical processes that are accounted for separately for each chemical in the mixture include vertical and horizontal dilution and transport, dissolution from droplet form, volatilization from the dissolved or surface phase, particulate adsorption/desorption and settling, degradation, and sedimentation to the sea floor. The general framework for the DREAM is shown in Fig. 5, in which $t$ is the current simulation time, $t_{\max }$ is the maximum simulation time (preset simulation period).

The currents for the fate/transport modeling were taken from the daily forecasts generated by the CANOPA (CANada Ocean PArallelise) ocean circulation model based on daily atmospheric forecast from the Canadian Meteorological Centre and five tidal constituents (Brickman and Drozdowski 2012). Although the model can produce salinity and temperature as well as currents at 


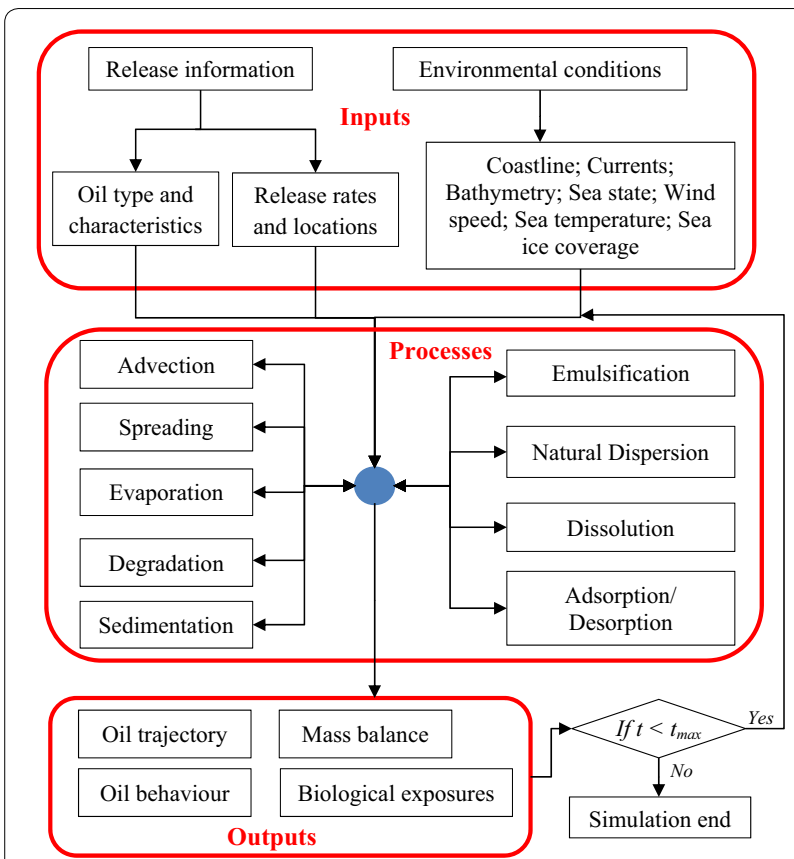

Fig. 5 The general framework for the DREAM (regenerated based on Reed and Hetland 2002)

$2 \mathrm{~h}$ intervals, the fate/transport modeling used the actual measured temperature and salinity for greater accuracy.

Four chemical groups, iron, ammonia, phenol, and PAHs, were chosen for modeling. The selection of iron, phenol and ammonia was due to their abundance in the produced water (as will be shown later), making them suitable as tracers. A domain of approximately $6 \mathrm{~km} \times 6 \mathrm{~km}$ was selected and was divided into $500 \times 500$ cells, the size of each cell being about $12 \mathrm{~m} \times 12 \mathrm{~m}$. The model used a time step of $1 \mathrm{~min}$, and an output interval of $10 \mathrm{~min}$.

\section{Results and discussion}

\section{Water column monitoring}

The chemical composition of produced water from the Venture platform is compared in Table 1 with data from the Thebaud platform on the Scotian Shelf, four platforms in the Norwegian sector of the North Sea, and the reference location (Ref.). Many of the components were of the same order of magnitude, but naphthalene from Venture was about 1/6 that of Thebaud and North Sea platforms. Concentrations of iron, ammonia, and barium in Venture produced water were much higher than those from other fields. Although the phenol concentration from Venture was lower than that of Thebaud, it was higher than the background level in seawater and needed to be closely examined.

CTD profiles for all the 28 stations are presented in Fig. 6. A detailed comparison of profiles at four stations in the south transect is shown in Fig. 7. Although the discharge had a salinity (203.50 ppt) much higher than that of the ambient seawater $(\sim 31.60 \mathrm{ppt})$, the measured profiles were all close to ambient. There was no clear trend in salinity or temperature with proximity to the platform. This was an indication that rapid dilution of the discharge resulted in a negligible effect on ambient salinity and temperature profiles. This can also be seen from the measured salinity and ammonia in water samples from these stations (Fig. 8). Although the measured profiles are not distance-dependent, Fig. 8 shows that time was a factor. Similar results were obtained for samples taken on the same day (July 5th) from two stations (S50 and S500), whereas 4 days later on the 9th, measurements from two other stations (S100 and S350) were again similar to each other, yet varied considerably from the July 5 th data. Some of the CTD profiles show very little stratification, while others show a thermocline at a depth of approximately $8 \mathrm{~m}$ (except the reference station). Again, this is mainly time-dependent rather than spatially-dependent.

The results for salinity, ammonia and three metals $(\mathrm{Fe}, \mathrm{Mn}$, and $\mathrm{Cu}$ ) are presented in Figs. 8 and 9. The stations SE5000 and the reference station (Ref) are plotted in red color. The background level is the average of data from the reference and SE5000 stations. Although values determined for the reference station may be used because it was located at a distance far enough from the platform as to be unaffected by the discharge, there may be a difference due to geographical location. As laboratory analyses revealed, concentrations of $\mathrm{Fe}$ and $\mathrm{Cu}$ at the reference station were in fact higher than most of the stations near the platform which contradicts the assumption that the reference station would have similar or lower values (Fig. 9). Therefore, if a relatively high background value based solely on the reference station had been used for comparative analyses, the significance of $\mathrm{Fe}$ and $\mathrm{Cu}$ at the stations near the platform would have been underestimated. Further, the station located southeast of the platform at a distance of about $5 \mathrm{~km}$ (SE5000) was not expected to exhibit any significant difference in background chemistry from seawater closer to the platform, however measured concentrations were not higher than the reference station, indicating negligible contamination from the discharge at SE5000. Therefore, seawater samples from as close as $5 \mathrm{~km}$ may also be used to determine background levels. For this study, the background values used were the averages of those from SE5000 and the reference station.

The closest station (S50) was $37.40 \mathrm{~m}$ from the platform, while the farthest was the reference station (Ref) at $18.71 \mathrm{~km}$. Although the salinity of raw produced water is about 6.40 times greater than that of the background level, there was no elevated salinity found at the stations 
Table 1 Comparison of chemical composition of produced water from Venture and other fields

\begin{tabular}{|c|c|c|c|c|c|}
\hline Component/field & Unit & Venture & Thebaud $^{\mathrm{a}}$ & North sea ${ }^{b}$ & $\begin{array}{l}\text { Reference location } \\
\text { (MID-depth) }\end{array}$ \\
\hline Salinity & ppt & 203.50 & 19.90 & - & 31.64 \\
\hline BTEX & $\mathrm{mg} / \mathrm{L}$ & 12.95 & 33.56 & 6.38 & $<1.00$ \\
\hline Total alkanes & $\mu g / L$ & 364.30 & 187.80 & - & $<0.10$ \\
\hline Naphthalenes & $\mu g / L$ & 187.20 & 1154.55 & 1280.00 & $<0.10$ \\
\hline Phenanthrenes & $\mu g / L$ & 11.00 & 5.35 & 71.80 & nd \\
\hline Dibenzothiophenes & $\mu g / L$ & 0.50 & 0.50 & 20.85 & nd \\
\hline Fluorene & $\mu \mathrm{g} / \mathrm{L}$ & 16.70 & 22.05 & 10.80 & nd \\
\hline Chrysene & $\mu g / L$ & 0.20 & nd & 0.27 & nd \\
\hline Total phenols & $\mu g / L$ & $10,530.00$ & $213,174.00$ & 7277.50 & $<0.10$ \\
\hline Cadmium & $\mu g / L$ & 2.00 & nd & $<0.0030$ & - \\
\hline Chromium & $\mu g / L$ & $<10.00$ & $<10.00$ & $<0.030$ & - \\
\hline Iron & $\mu \mathrm{g} / \mathrm{L}$ & $137,000.00$ & $16,700.00$ & 6875.00 & 1.84 \\
\hline Copper & $\mu g / L$ & $<10.00$ & $<10.00$ & $<0.03$ & 0.15 \\
\hline Manganese & $\mu g / L$ & $24,100.00$ & 2100.00 & - & 0.48 \\
\hline Mercury & $\mu \mathrm{g} / \mathrm{L}$ & 0.10 & 0.06 & 0.020 & - \\
\hline Nickle & $\mu g / L$ & $<20.00$ & $<20.00$ & $<0.030$ & 0.25 \\
\hline Zinc & $\mu g / L$ & 2400.00 & 73.50 & 145.50 & - \\
\hline Lead & $\mu g / L$ & 27.00 & 3.00 & $<0.013$ & 0.10 \\
\hline Barium & $\mu \mathrm{g} / \mathrm{L}$ & $1240,000.00$ & $102,000.00$ & $156,000.00$ & - \\
\hline Silicate & $\mu \mathrm{M} / \mathrm{L}$ & 374.30 & $80.70^{d}$ & - & 0.12 \\
\hline Nitrate & $\mu \mathrm{M} / \mathrm{L}$ & 1.30 & $0.80^{d}$ & - & 0.76 \\
\hline Ammonia & $\mu M / L$ & $22,518.00$ & $2737.00^{d}$ & $1174.00^{c}$ & 0.53 \\
\hline Nitrite & $\mu \mathrm{M} / \mathrm{L}$ & 1.70 & $0.80^{d}$ & - & 0.14 \\
\hline
\end{tabular}

a Average value of 2009 and 2007 data

b Average value from four fields, Utvik (1999)

c Data from Somerville et al. (1987)

d Only 2009 data are available, nd not detected, - no data
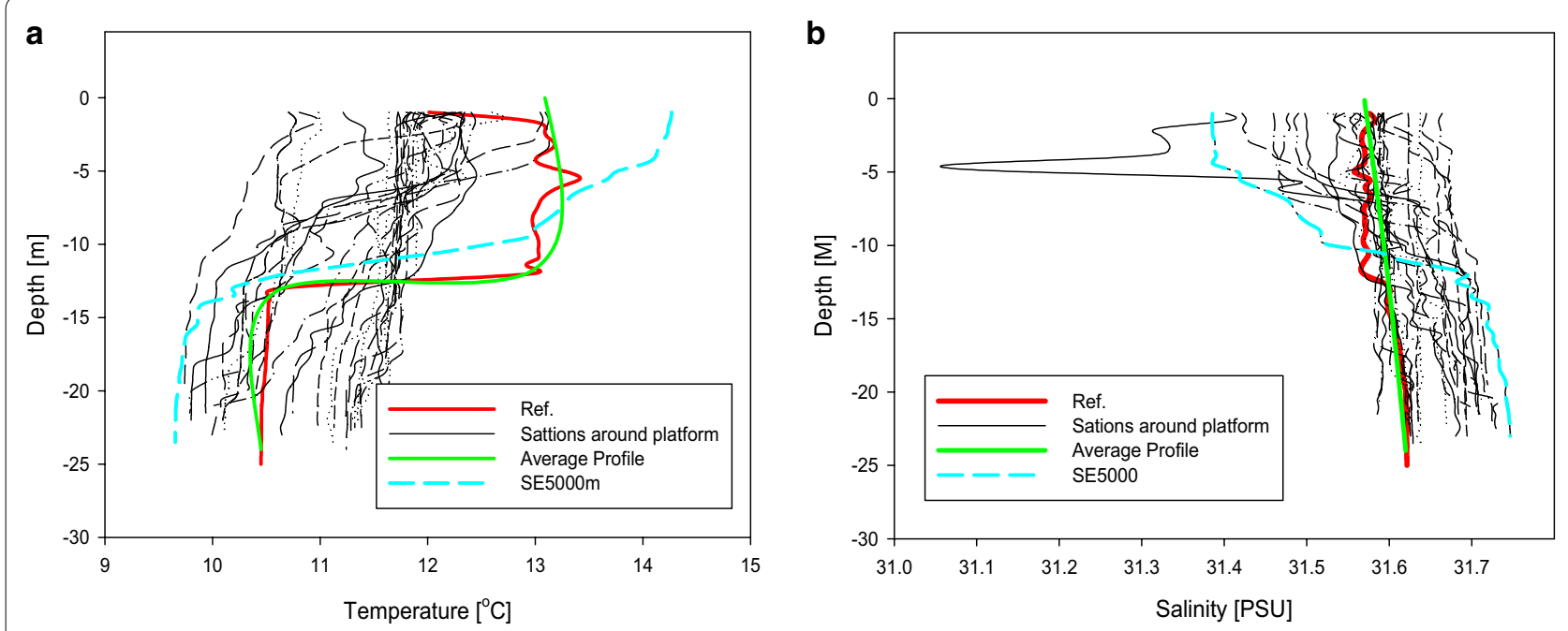

Fig. 6 a Temperature and $\mathbf{b}$ salinity profiles for all stations with the averaged (green) profile used in modeling 

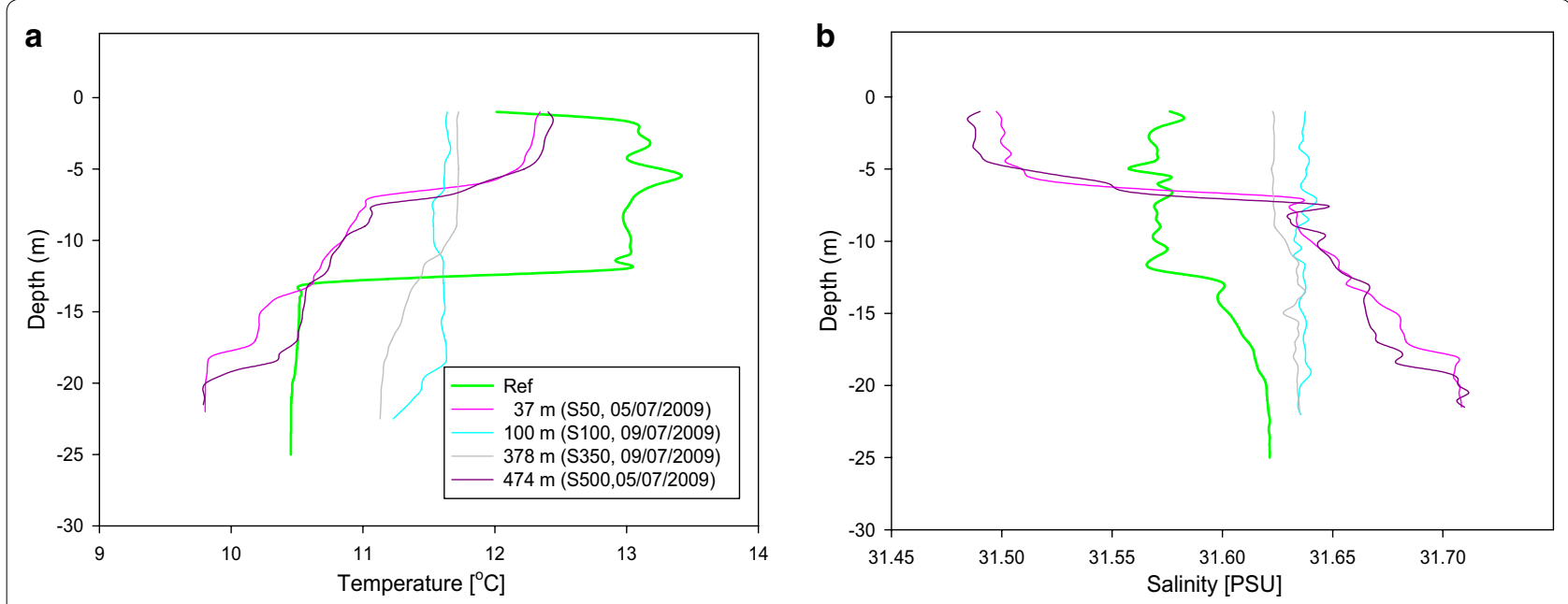

Fig. 7 a Temperature and $\mathbf{b}$ salinity profiles in the south transect
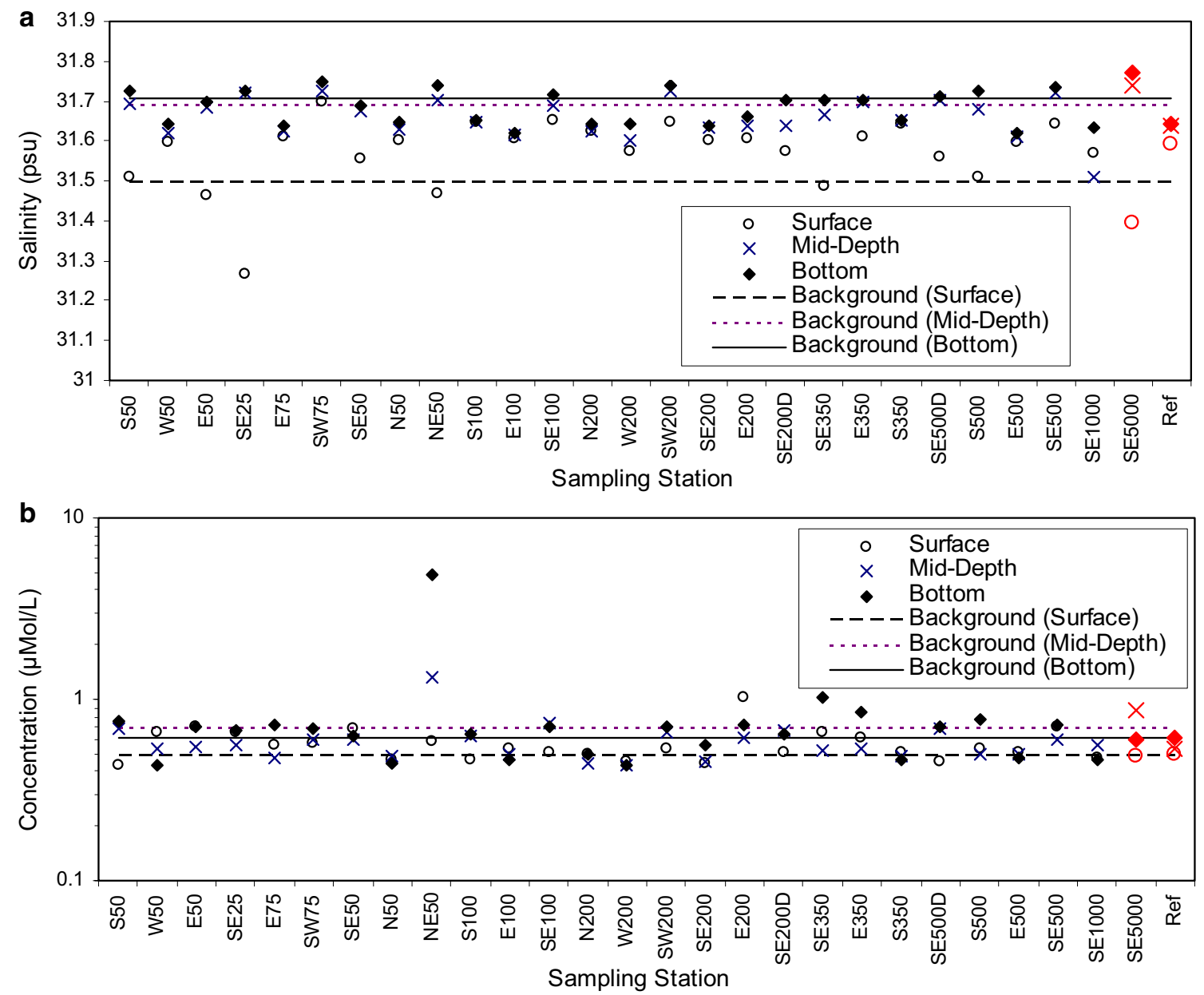

Fig. 8 Measured a salinity and $\mathbf{b}$ ammonia around the Venture platform and at the reference station (Ref) 

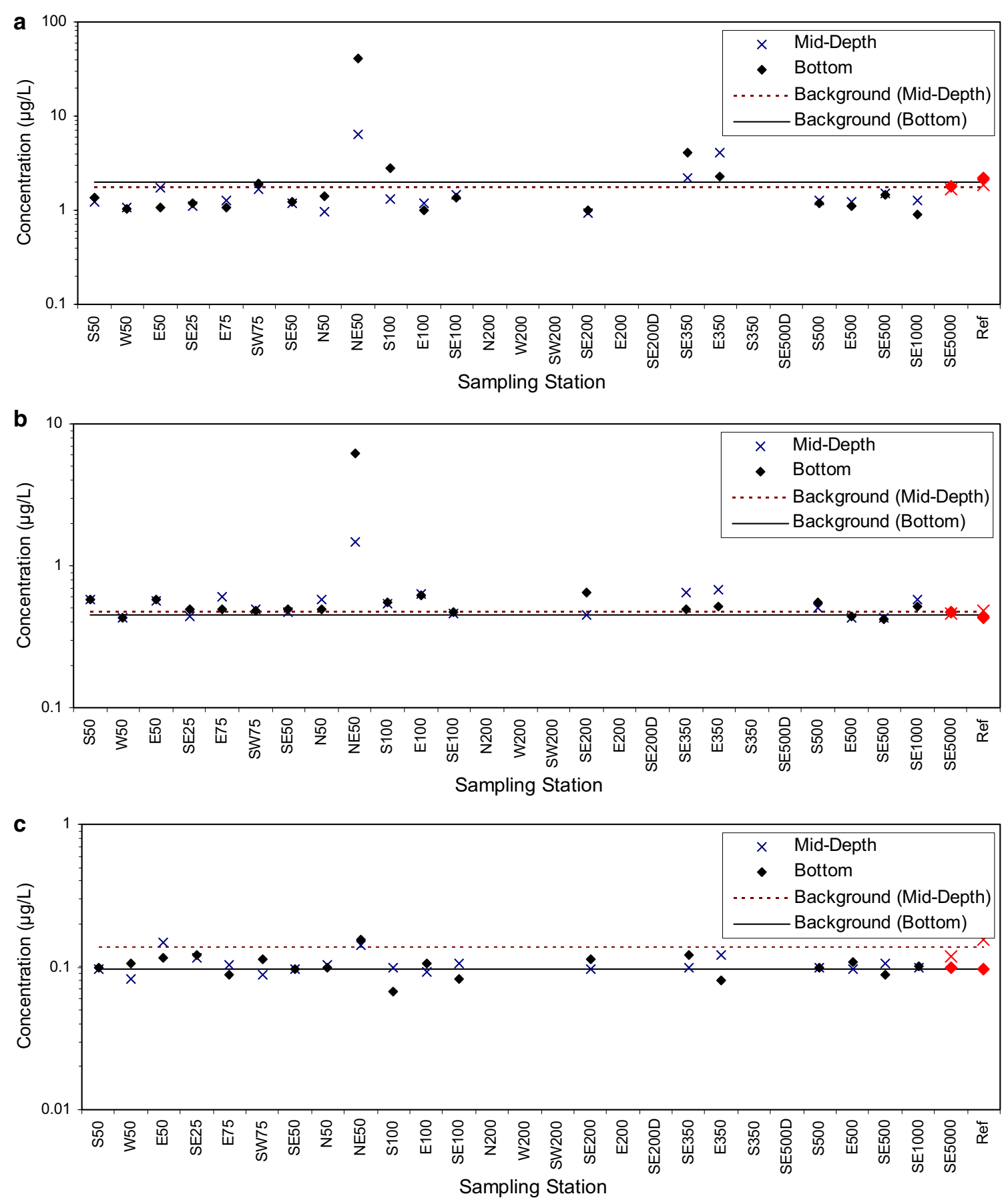

Fig. 9 Measured concentrations of $\mathbf{a}$ iron, $\mathbf{b}$ manganese and $\mathbf{c}$ copper around the Venture platform and at the reference station (Ref)

(Figs. 7, 8). The slightly elevated salinity at some stations within $1000 \mathrm{~m}$ from the platform was considered a result of uncertainties associated with the natural environment, sampling and analysis, because it did not exceed the salinity at SE5000.
While most of the data for ammonia showed a similar pattern to that exhibited by salinity, the NE50 station had a level significantly higher than others. The concentration at the bottom for NE50 was about 7.9 times the background level. This was an indication of a traceable 
amount of produced water present near the bottom, and this is possible because the ammonia concentration in raw produced water is about 36,945 times the background. Furthermore, the elevated concentration of $\mathrm{Fe}$ and $\mathrm{Mn}$ in the same sample confirmed the likely presence of produced water (Fig. 9). The concentration at mid-depth is about 1.8 times the background level, which may be caused by the presence of produced water, or be the result of uncertainties, since the $C / C_{a}$ ratio of 1.80 at mid-depth for NE50 is not significantly higher than 1.23 at SE5000 from which the background level was determined (Fig. 10).

Although the silicate was not as abundant as ammonia, its level in raw produced water was about 925 times the background, so it may also be used as tracer to determine the presence of produced water. Although the silicate concentrations at SW75 and SW200 (Fig. 10) appeared to be several times higher than the background, it cannot be construed that produced water is present, as there is no elevation in concentration of other chemicals, especially ammonia and iron, which are good tracers due to their abundance in raw produced water. The measured nitrate and nitrite concentrations are all close to the background level. This is reasonable as their initial concentrations are only 12.90 (nitrite) and 1.30 (nitrate) times the background level, and therefore they can be easily diluted to a level near background once discharged.

As the iron and manganese levels in raw produced water were 68,792 and 53,142 times the background, they made good tracers. The results for iron and manganese were similar to those for ammonia, and their elevated concentrations are shown in the bottom sample from NE50 (Figs. 9, 10). This confirms the presence of produced water at NE50. The initial concentration of copper in raw produced water is 103 times less than the background, so dilution has reduced its concentration, even at NE50, to near background.

For the organics, highly variable concentrations of alkanes were observed. Elevated levels of alkanes, three times greater than background, were observed in samples recovered from five stations. While the majority of the stations exhibited phenol levels below detection limits, elevated levels of phenol were also found at the NE50 station. PAHs were detected only at NE50, but the levels were only slightly above the detection limit. The concentrations of BTEX and petrogenic compounds (e.g., phenanthrenes) were below the detection limits for any of the 28 stations.

Total phenols in raw produced water was about 15,882 times the background and therefore phenol can also be used as a tracer to track the produced water discharge. The phenol data was consistent with other data (Fig. 10) and was only elevated at NE50. For other hydrocarbons, all stations had a level below the detection limit, except naphthalene, at NE50 which had a level (102.80 ng/L) slightly above the limit $(100.00 \mathrm{ng} / \mathrm{L})$.

For the water samples collected at the 26 stations (excluding SE5000 and the reference station), the analysis of ammonia, iron, manganese, phenol and naphthalene indicated the presence of produced water of elevated level at the bottom sample from NE50 only. Concentrations of these chemicals were also slightly elevated at this station in the mid-depth sample. This suggests that the produced water plume was close to the bottom but extended to the mid-depth. From the bottom sample data, an average dilution factor of 5003.00 was calculated (Fig. 11). The comparison of relationship between $C_{0} / C_{\mathrm{a}}$ (ratio of discharge concentration to ambient concentration) and $C / C_{\mathrm{a}}$ (ratio of environmental concentration to ambient concentration) for the different chemicals

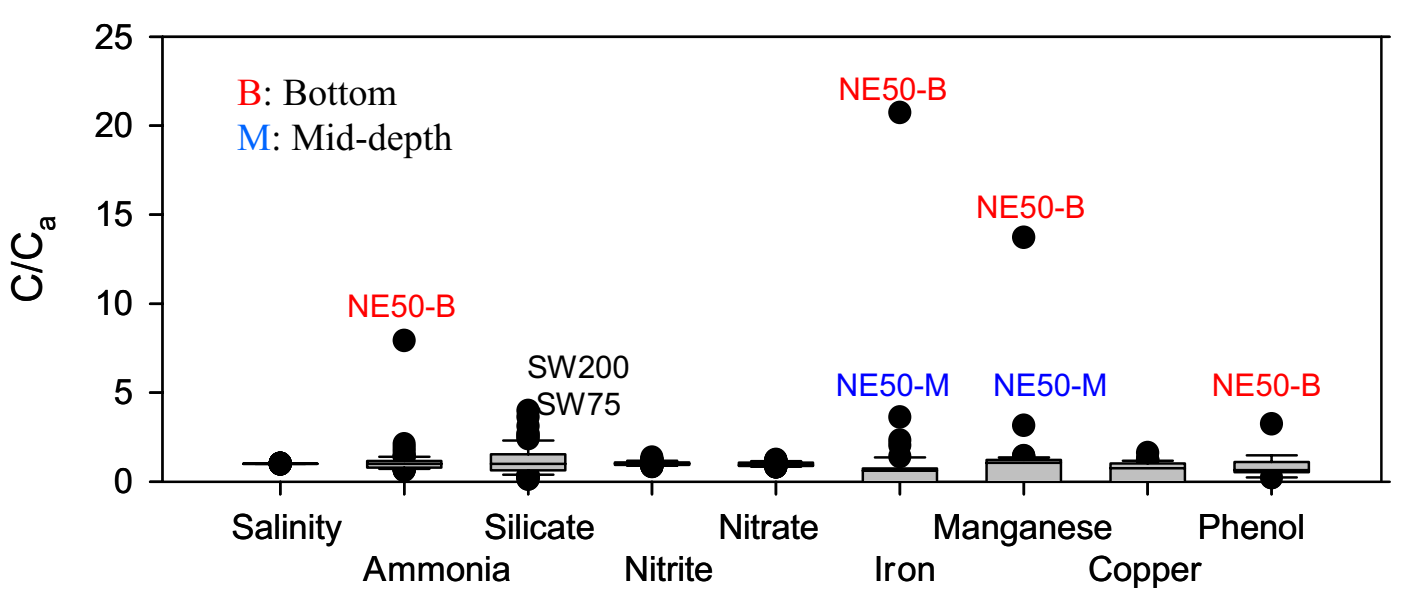

Fig. 10 Boxplot of measured concentrations $(C)$ normalized to background level $\left(C_{a}\right)$ 

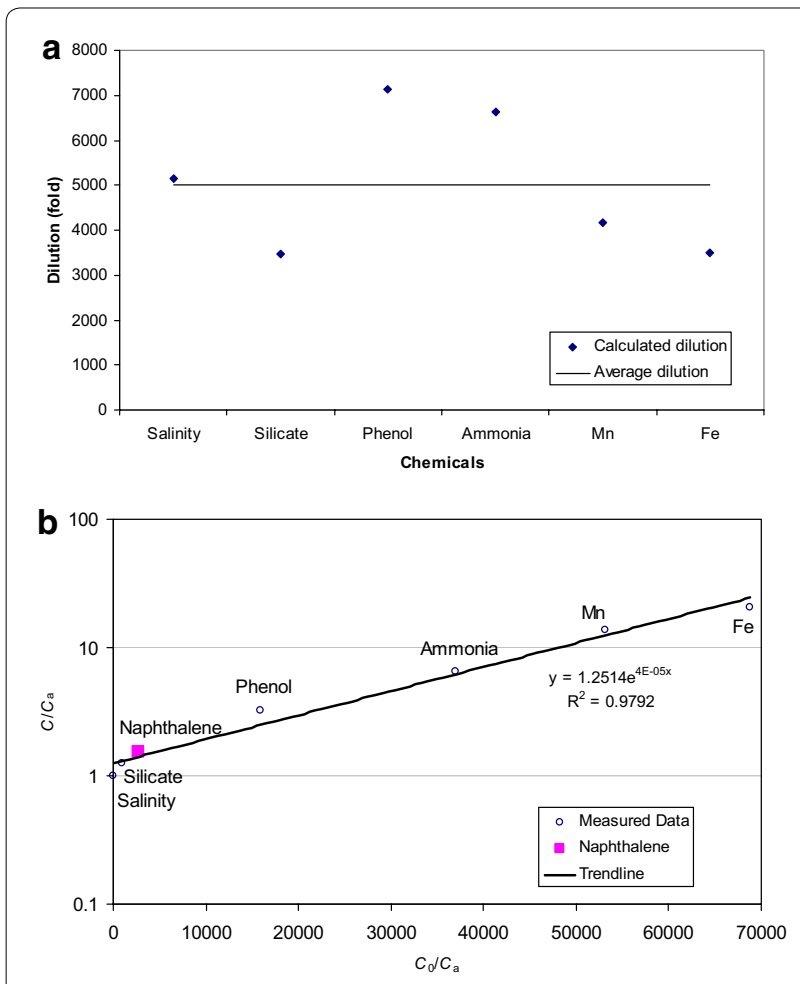

Fig. 11 Calculated $\mathbf{a}$ dilution ratio and $\mathbf{b}$ relationship showing the increased chemical concentration ratio (C/Ca) with increased initial discharge to ambient concentration ratio $\left(\mathrm{C}_{0} / \mathrm{Ca}\right)$

(tracers) suggested that the data were of reasonably good quality, because $C / C_{\mathrm{a}}$ was a function of the dilution ratio, $C_{0} / C_{\mathrm{a}}$ (Fig. 11). Since $C_{\mathrm{a}}$ for naphthalene was below the detection limit and it could not be directly plotted in the figure, the calculated dilution ratio was used to estimate the ambient concentration, and then the $C_{0} / C_{\mathrm{a}}$ and $C / C_{\mathrm{a}}$ ratios. The data fitted the trend line well, and confirm the good quality of the data and estimated dilution ratio.

In summary, the water column monitoring found no significantly elevated chemical concentrations at any of the sampling stations except NE50. The question arises, why were there no elevated chemical levels at most of these stations except NE50. To answer this question, a mathematical fate and transport model is needed to visualize the transport processes of produced water.

\section{Fate and transport modeling}

The predicted produced water plume (total concentration of chemical mixture) profiles at $0.5,1,2.5$ and 5 days showed that a narrow plume (width $=\sim 100 \mathrm{~m}$ ) constantly changed location with the tidal currents (Fig. 12). The vertical profiles indicated that the plume sank and spread out on the bottom after discharge. The maximum concentration of the chemical mixture was approximately $28.00-35.00 \mathrm{ppb}$.
To study the variation of produced water concentration in terms of $C / C_{0}$ along the plume centerline, a profile at 1 day $5 \mathrm{~h}$ were plotted (Fig. 13). The concentration ratio was calculated using iron as a conservative tracer versus the background level of iron in seawater. One day $5 \mathrm{~h}$ was chosen because the produced water discharge rate was at its maximum $\left(133.00 \mathrm{~m}^{3} /\right.$ day $)$ and current speed was close to the minimum at that time. As a result, the dilution rate and concentrations represented a worst case scenario. It can be seen that the maximum instantaneous concentration ratio along the centerline was less than $0.05 \%$ which is much smaller than the critical level of $0.20 \%$ (calculated based on produced water to seawater volume ratio $V_{P W} / V_{S W}=0.25 \%$ using iron as a conservative tracer) for effects on productivity. Therefore, it is not expected that produced water will pose adverse effects on bacteria except in the immediate vicinity of the discharge pipe.

The predicted produced water profiles at 9:20 a.m. and 16:00 p.m., July 4, 2009 are shown in Fig. 14. These two time steps were used instead of the real sampling time of 9:21 a.m. and 16:02 p.m. (with a small difference of 1-2 min), because the model output was at $10 \mathrm{~min}$ intervals. The plume profiles are not expected to change much within such as short period of time, so they are considered good representations of the profile at the time of sampling and can be used for comparison.

Since the plume was very narrow in nature, sampling (for example at SE25 as shown in Fig. 14) often missed it, resulting in a concentration near the background level (Figs. 9, 15). This is the case for most of the sampling stations except the NE50 which was taken inside the plume boundary (Figs. 14, 15).

A comparison of modeled and measured concentrations for iron, ammonia, phenol and naphthalene at the bottom- and mid-depths were conducted (only results for Iron at bottom level were shown in Fig. 15). Based on these results the following is clear.

- The model predicted the dilution very well. The ratios of measured to predicted concentrations for the near bottom sample were 1.55, 1.12, 1.12 and 1.25 for iron, ammonia, phenol and naphthalene, respectively. The mean value was 1.26 .

- For the mid-depth sample, the ratios of measured to predicted concentrations were $0.88,0.77$ and 1.56 for iron, ammonia and phenol. The mean value was 1.07. The model predicted a naphthalene concentration of $17.00 \mathrm{ppt}$ which was below the detection limit and agreed with the non-detectable level of naphthalene for this sample.

- The model predicted the plume location well. 


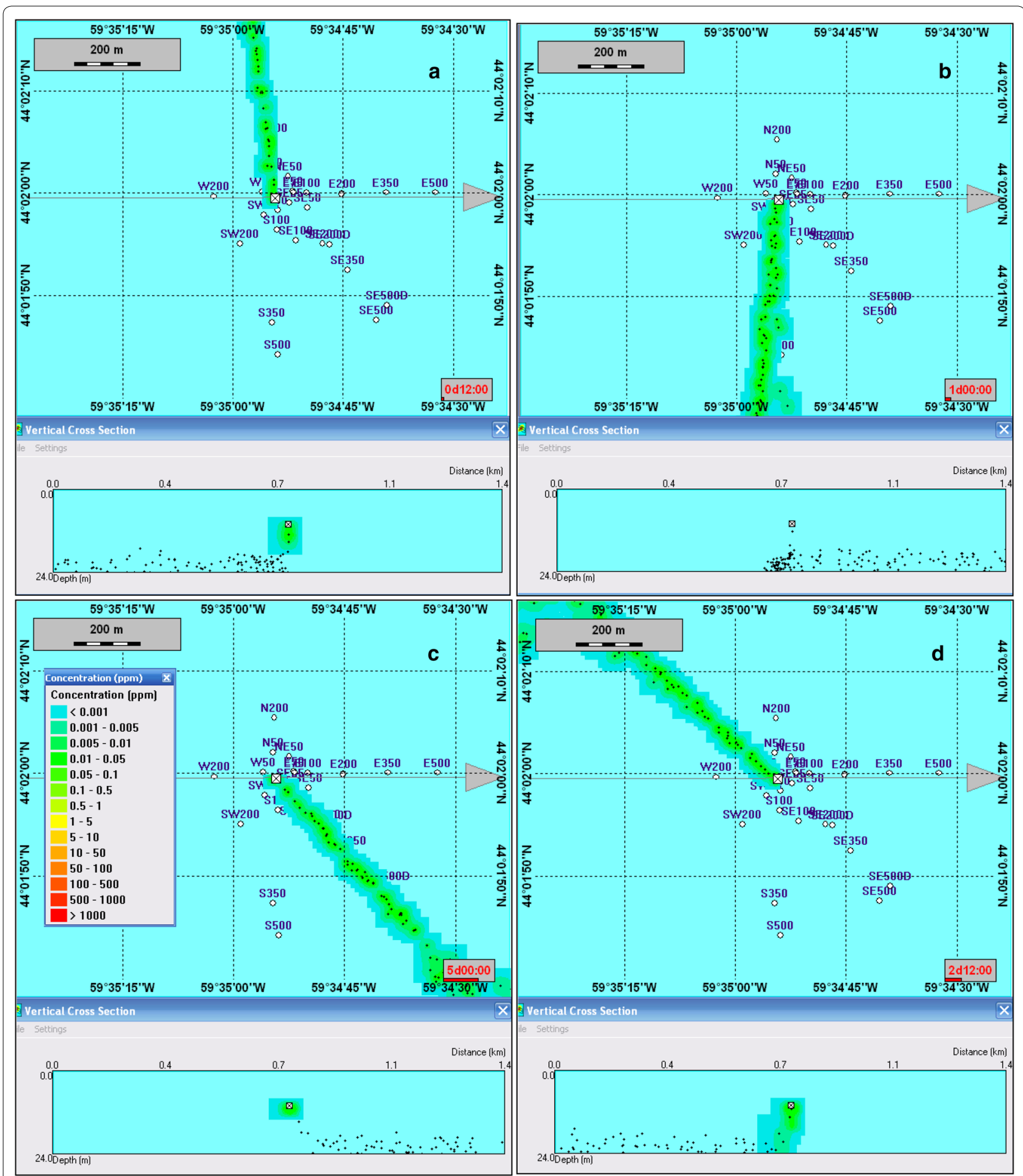

Fig. 12 Horizontal (top section) and vertical (bottom section) dispersion of produced water total concentration of chemical mixture at $\mathbf{a} 0.5, \mathbf{b} 1, \mathbf{c}$ 2.5 , and $\mathbf{d} 5$ days

The modeling results indicated that although the random sampling approach used in this study had the advantage of exposing the overall environmental concentrations around the platform, and informed whether there was an accumulation after long term discharge, it had the limitation of not being able to consistently provide detailed 


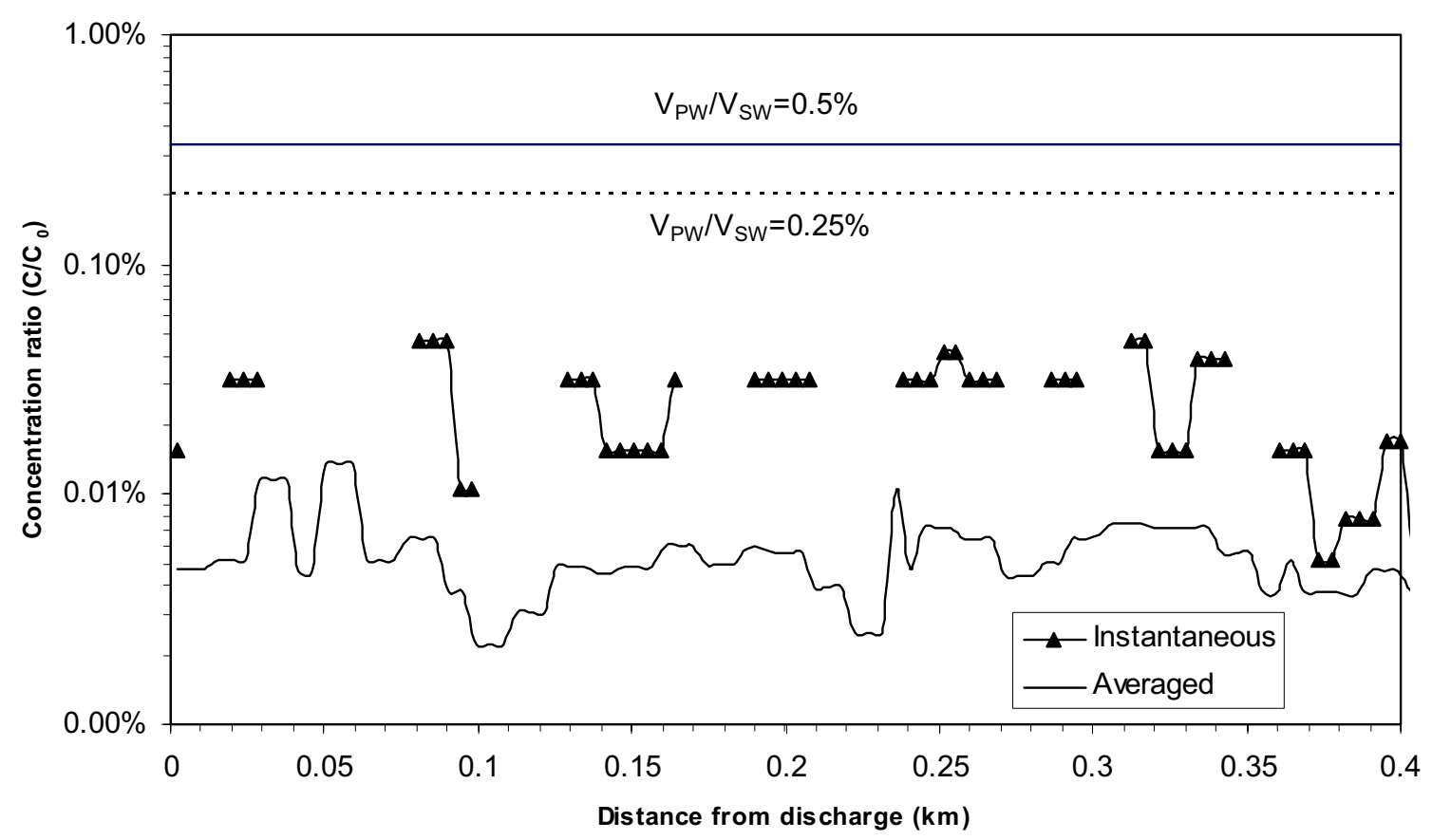

Fig. 13 Concentration ratio along plume center line (6:00 a.m., July 4, 2009) calculated using Fe as a conservative tracer
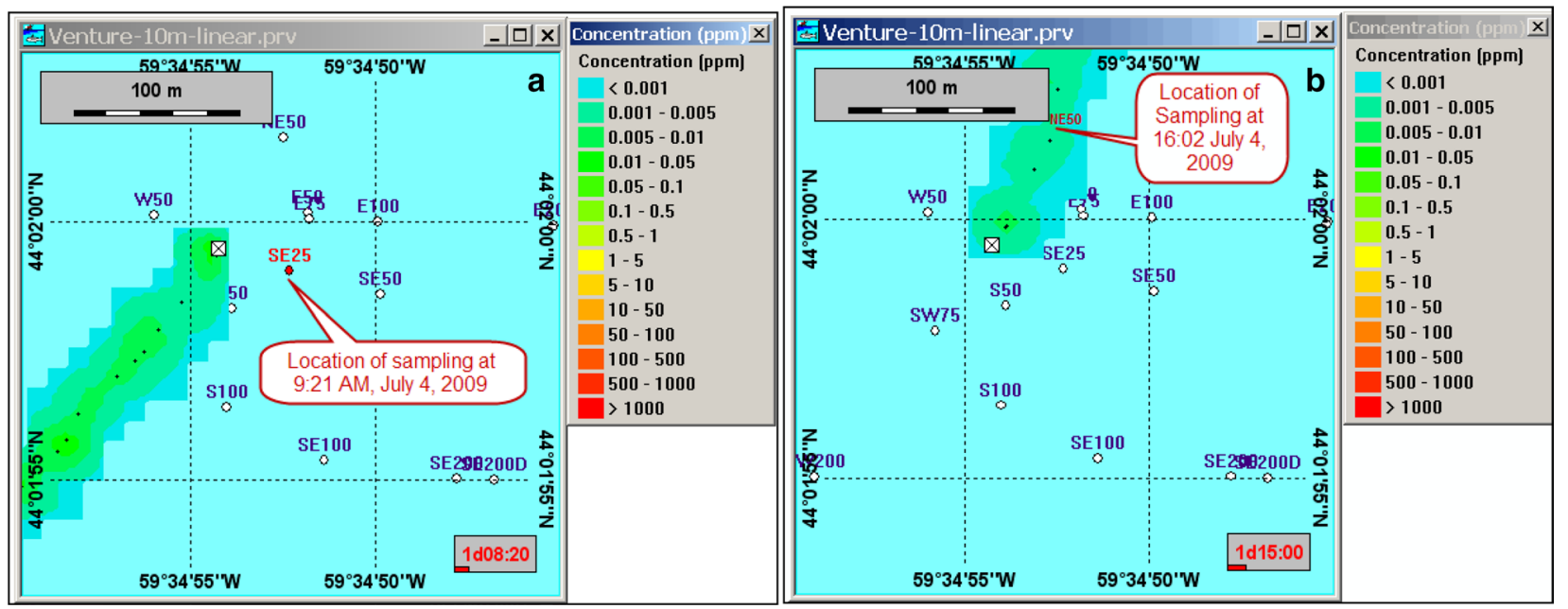

Fig. 14 Concentration of Fe at a 9:20 a.m. and b 16:00 p.m. on July 4, 2009

information inside the plume, nor could it provide information on the dimensions of the plume.

\section{Conclusions and recommendations}

In this study, the raw produced water from the Venture platform was characterized. Phenols and BTEX were the most abundant organic constituents. The concentrations of hydrocarbons including aliphatic hydrocarbons (alkanes) and PAHs contributed to $<1.00 \%$ of the total organic. The produced water discharge stream from the Venture platform was highly saline and had higher concentrations of ammonia, silicate, barium, iron, manganese and zinc than Thebaud and North Sea fields.

To assess the impact zone of Venture produced water effluents, a water sampling program was conducted and samples from 28 stations (including reference) at three 

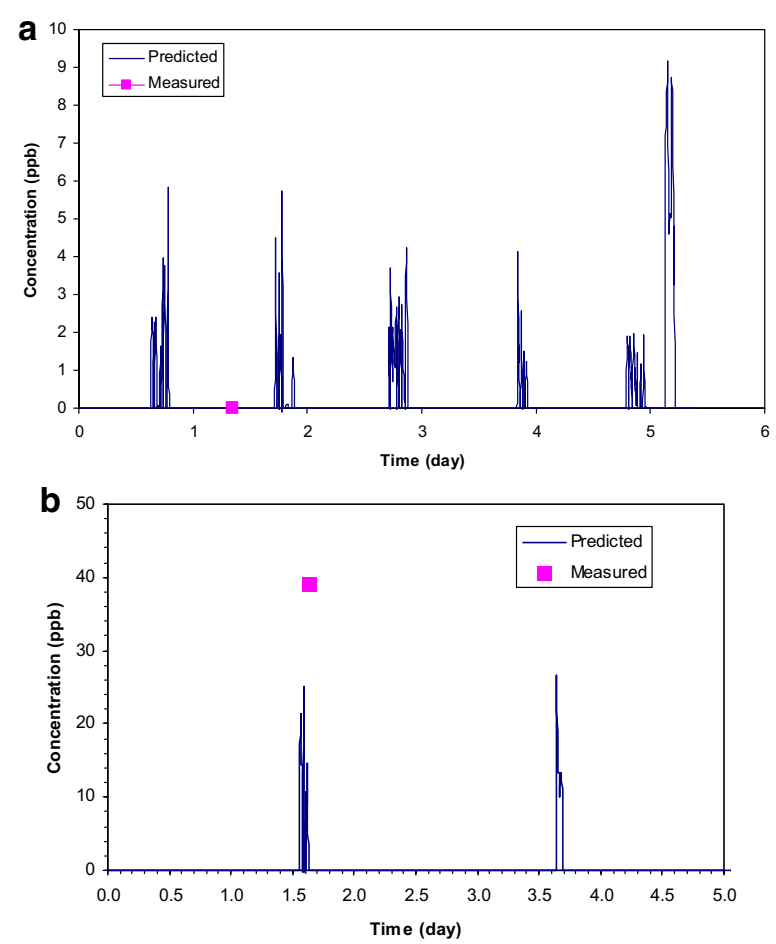

Fig. 15 Comparison of model simulation (time series) of Fe concentrations (ppb) with observations (at specific sampling time) in station a SE 25 and b NE50

depths were taken at various distances around the platform. Except for station NE50, all 26 stations showed near background levels of organic and inorganic compounds. The NE50 station had elevated levels of PAHs, phenols, nutrients, iron and barite. The levels were several times greater than background levels and indicated that produced water was detectable at NE50 at the time of sampling.

Although the concentrations of alkanes were found to be more than three times the background levels at a number of stations, they were considered to be effects of uncertainties rather than indications of the influence of produced water. This was concluded by examination of the $\mathrm{Fe}$ concentrations at these same stations relative to concentrations in the discharge stream. Since the concentrations of Fe were essentially at background levels, either the dilution rates were very high $(73,200: 1)$ or produced water was absent. As it only requires a much lower dilution rate for alkanes in the discharge stream to reach background levels, it is concluded that produced water is a negligible contributor and the observed elevations of alkanes were due to uncertainties.

To help interpret the measured data and understand the transport behaviour of produced water, a modeling study was performed. Modeling revealed that the near background level concentrations detected at the 26 stations were due to sampling outside the narrow plume boundary. This indicated that there was no accumulation of pollutants near the platform except inside the narrow plume. The ratios of measured to predicted concentrations for the near bottom sample were 1.25 for naphthalene, indicating a slight underestimation of the model. For the mid-depth sample, the model predicted a naphthalene concentration below the detection limit which agreed with the non-detectable level of naphthalene for this sample.

The comparison of modeled and empirical data showed that the DREAM model can effectively predict plume behaviour. However, due to the limitation of the randomized sampling strategy, only limited information from NE50 could be used to validate the model. A modified sampling design based on real time local currents would permit the collection of more pertinent information to validate the model in detail.

Detecting the plume is challenging for a number of reasons, including large dilution factors as a result of the relatively low produced water discharge from Venture (approximately $100.00 \mathrm{~m}^{3} /$ day), movement of the plume due to tides and currents, and the relatively low solubility and high volatility of many produced water constituents. To overcome some of these challenges, future research should focus on using real-time tidal and current models to predict the direction of the produced water plume so that samples can be collected at appropriate locations.

\section{Authors' contributions}

HN designed the sampling program, carried out the onsite sampling, conducted the simulation model, and prepared the drafted manuscript. KL is the manager of the research project. He designed the sampling program and provided overall review of the drafted manuscript. BR and SC carried out the onsite sampling, conducted the sample and data analyses, and prepared the corresponding sections for the drafted manuscript. PL conducted the simulation model and the corresponding data analysis, and prepared the drafted manuscript. All authors read and approved the final manuscript.

\section{Author details}

${ }^{1}$ Department of Engineering, Dalhousie University (Truro Campus), Truro, NS B2N 5E3, Canada. ${ }^{2}$ Weath from the Oceans Flagship, CSIRO, Perth, Australia. ${ }^{3}$ Centre for Offshore Oil, Gas and Energy Research (COOGER), Fisheries and Oceans Canada, Bedford Institute of Oceanography, Dartmouth, NS B2Y 4A2, Canada.

\section{Acknowledgements}

We gratefully acknowledge Peter Thamer for his technical assistance in the field and in the microbiology and chemistry lab, Jennifer Mason for organics analysis, Carol Anstey for nutrient analysis and Byron Amirault for metal analysis. This study was funded by the Program on Energy Research and Development (PERD) and Environmental Studies Research Funds (ESRF). ExxonMobil Canada East provided logistical support. SINTEF supplied the DREAM modeling package.

Competing interests

The authors declare that they have no competing interests. 
Received: 3 May 2016 Accepted: 27 June 2016

Published online: 07 July 2016

\section{References}

AMEC and Conestoga-Rovers and Associates (2008) Annual report offshore environmental effects monitoring program. Submitted to ExxonMobil Canada Properties-Sable Offshore Energy Project by AMEC and Conestoga-Rovers and Associates on behalf of ACCENT Engineering Consultants Inc. http://www.cnsopb.ns.ca/sites/default/files/pdfs/2008_ annual_report_soep_eem.pdf. Accessed 2 July 2015

Armstrong FAJ, Stearns CR, Strickland JDH (1967) The measurement of upwelling and subsequent biological process by means of the Technicon Autoanalyzer ${ }^{\circledR}$ and associated equipment. Deep Res 14:381-389

Bakke T, Klungsøyr J, Sanni S (2013) Environmental impacts of produced water and drilling waste discharges from the Norwegian offshore petroleum industry. Mar Environ Res 92:154-169

Brickman D, Drozdowski A (2012) Development and validation of a regional shelf model for maritime Canada based on the NEMO-OPA circulation model. Canadian Technical Report of Hydrography and Ocean Sciences, 278. http://www.dfo-mpo.gc.ca/Library/347377.pdf. Accessed 2 July 2015

CNSOPB (2010) Sable offshore energy project production report. Canada Nova Scotia Offshore Petroleum Board. http://www.cnsopb.ns.ca/offshoreactivity/production-data. Accessed 2 July 2015

DeBlois EM, Leeder C, Penney KC, Murdoch M, Paine MD, Power F, Williams UP (2004) Terra Nova environmental effects monitoring program: from environmental impact statement onward. In: Armsworthy SL, Cranford PJ, Lee K (eds) Offshore oil and gas effects monitoring: approaches and technologies. Battelle Press, Columbus, pp 475-492

DFO (2009) Review of ExxonMobil Canada's 2008 offshore environmental effects monitoring report. Department of Fisheries and Oceans Canada, Canadian Science Advisory Secretariat Science Response 2009/008. http://www.dfo-mpo.gc.ca/Library/338070.pdf. Accessed 2 July 2015

DFO (2014) The Gully. Department of Fisheries and Oceans Canada. http:// www.dfo-mpo.gc.ca/oceans/marineareas-zonesmarines/mpa-zpm/ atlantic-atlantique/gully-eng.htm. Accessed 2 July 2015

Durell G, Johnsen S, Utvik TR, Frost T, Neff J (2004) Produced water impact monitoring in the Norwegian sector of the North Sea: overview of water column surveys in the three major regions. In: Proceedings of SPE international conference on health, safety and the environment in oil and gas exploration and production, Calgary, p 1-15

Durell G, Utvik TR, Johnsen S, Frost T, Neff J (2006) Oil well produced water discharges to the North Sea. Part I: comparison of deployed mussels (Mytilus edulis), semi-permeable membrane devices, and the DREAM model predictions to estimate the dispersion of polycyclic aromatic hydrocarbons. Marine Environmental Research 62:194-223

Fraser GS, Russell J, Von Zharen WM (2006) Produced water from offshore oil and gas installations on the Grand Banks, Newfoundland: are the potential effects to seabirds sufficientl known? Marine Ornithology 34:147-156

Hylland K, Tollefsen KE, Ruus A, Johnson G, Josson G, Sundt RC, Sanni S, Utvik TIR, Johnsen S, Nilssen I, Pinturier L, Balk L, Baršiené J, Marigòmez I, Feist SW, Børseth JF (2008) Water column monitoring near oil installations in the North Sea 2001-2004. Mar Pollut Bull 56:414-429

Johnsen S, Røe TI, Durell G, Reed M (1998) Dilution and bioavailability of produced water compounds in the Northern North Sea, a combined modeling and field study. Proceedings of the SPE International Conference on Health. Safety and the Environment in Oil and Gas Exploration and Production, Caracas, pp 1-11
Kérouel R, Aminot A (1997) Fluorometric determination of ammonia in sea and estuarine waters by direct segmented flow analysis. Mar Chem 57:265-275

Lee K., Azetsu-Scott K., Cobali S. E., Dalziel J., Niven S., Wohlgeschaffen G., Yeats P. (2004) Overview of potential impacts from produced water discharges in Atlantic Canada. In: In: S. L. Armsworthy, P. J. Cranford, K. Lee, (ed.), Offshore Oil and Gas Effects Monitoring: Approaches and Technologies (pp.319-342). Battelle Press

Murphy J, Riley JP (1962) Anal Chim Acta 27:31-36

Neff J (2002) Bioaccumulation in Marine Organisms: Effects of Contaminants from Oil Well Produced Water. Elsevier, The Netherlands

Neff J, Johnsen S, Frost T, Utvik TI, Durell G (2006) Oil well produced water discharges to the North Sea. Part II: comparison of deployed mussels (Mytilus edulis) and the DREAM model to predict ecological risk. Mar Environ Res 62:224-246

Reed M, Hetland B (2002) DREAM: a dose-related exposure assessment model technical description of physical-chemical fates components. In: Proceedings of the SPE international conference on health, safety and environment in oil and gas exploration and production, Kuala Lumpur, p $1-23$

Reed M, Rye H (2011) The DREAM model and environmental impact factor: decision support for environmental risk management. In: Lee K, Neff J (eds) Produced water: environmental risks and advances in mitigation technologies. Springer, New York, pp 189-203

Sea-Bird Electronic Inc. (2009) SBE25 sealogger CTD user's manual. http:// www.seabird.com/sites/default/files/documents/25_017.pdf. Accessed 1 July 2016

Somerville HJ, Bennett D, Davenport JN, Holt MS, Lynes A, Mahieu A, McCourt B, Parker JG, Stephenson RR, Watkinson RJ, Wilkinson TG (1987) Environmental effect of produced water from North Sea oil operations. Mar Pollut Bull 18:549-558

Strickland JDH., Parsons TR (1972) A practical handbook of seawater analysis, fisheries research board of Canada, Bulletin 167. http://www.dfo-mpo. gc.ca/Library/1507.pdf. Accessed 22 Aug 2014

Technicon Industrial Systems (1973) Orthophosphate in water and seawater Industrial Method 155-71W

Technicon Industrial Systems (1977), Silicates in water and seawater, Autoanalyzer II Industrial Method No. 186-72W

Technicon Industrial Systems (1979) Nitrate and nitrite in water and seawater, Auto analyzer II Industrial Method No. 158-71W

US EPA (1994) Method 8240B volatile organic compounds by gas chromatography/mass spectrometry (GC/MS). United State Environmental protection Agency. http://www.caslab.com/EPA-Methods/PDF/8240B. pdf. Accessed 22 Aug 2014

US EPA (2007a) Method 8270 semivolatile organic compounds by gas chromatography/mass spectrometry (GC/MS). United State Environmental protection Agency. http://www.epa.gov/osw/hazard/testmethods/ sw846/pdfs/8270d.pdf. Accessed 22 Aug 2014

US EPA (2007b) Method 8041 phenols by gas chromatography. United State Environmental protection Agency. http://www.epa.gov/osw/hazard/testmethods/sw846/pdfs/8041a.pdf. Accessed 22 Aug 2014

Utvik TIR (1999) Chemical characterisation of produced water from four offshore oil production platforms in the North Sea. Chemosphere 39:2593-2606

Willie SN, lida Y, McLaren JW (1998) Determination of Cu, Ni, Zn, Mn Co, Pb, $\mathrm{Cd}$, and $\mathrm{V}$ in seawater using flow injection ICP-MS. J Anal At Spectrom 19:67-72 